\title{
Solid organs transplanted from HIV-positive dead donors to HIV-negative recipients: should it be allowed?
}

\author{
Magda Slabbert \\ $B A$ (Hons) HED BProc LLB LLD (UFS) \\ Professor: Department of Jurisprudence, University of South Africa
}

\begin{abstract}
OPSOMMING
Moet dit toegelaat word om MIV-positiewe organe van kadawer skenkers oor te plant in MIV-negatiewe pasiënte?
\end{abstract}

Amerikaanse wetgewing laat die oorplanting van MIV-positiewe geskente organe toe vir inplanting in MIV-positiewe pasiënte. Suid-Afrika het geen wetgewing rondom die oorplanting van MIV-positiewe geskenkte organe nie. Navorsing is wel gedoen rondom die oorplanting van soliede organe wat deur MIV-positiewe mense geskenk is en toe oorgeplant is in MIVpositiewe mense op die oorplantingswasglys. Sulke oorplantings was suksesvol. Die vraag het dus onstaan of weens die knellende te kort aan geskenkte organe daar oorweeg moet word om MIV-positiewe organe oor te plant in MIV-negatiewe pasiënte. Hierdie opsie het beide regs- en etiese implikasies. Aangesien dit nie algemeen gedoen word nie, behoort dit as navorsing gesien te word en derhalwe moet daar streng aan wetgewing waar mense vir navorsing gebruik word, voldoen word. Om MIV-positiewe organe in MIV-negatiewe ontvangers oor te plant behoort die allerlaaste uitweg te wees om orgaantekorte aan te spreek, ander maniere van orgaanverkryging in ander dele van die wêreld wat nog nie deur SuidAfrika ondersoek is nie, behoort eers ondersoek te word alvorens HIVpositiewe organe gebruik word.

\section{Introduction}

The National Organ Transplant Act (NOTA), a federal law, was passed in 1984 in the United States of America. In 1988 it was amended to ban organ donations from HIV-positive donors. ${ }^{1}$ The Act prohibited the recovery of organs from donors infected with the etiologic agent for acquired immune deficiency syndrome.' 2 The wording did not specifically refer to the human immunodeficiency virus (HIV), ${ }^{3}$ but it was interpreted as such. During that time the medical community did not know that HIV was the virus that caused the acquired immune deficiency

1 Public Law 100-607, Title IV, s 403(a)(3) §628(2)(C) of NOTA.

$2 \quad$ Ibid.

3 HIV can lead to acquired immunodeficiency syndrome or AIDS if not treated. The human body cannot get rid of HIV even with treatment. Once you get HIV you have it for life. HIV attacks the body's immune system, specifically the CD4 cells (T cells), which help the immune system fight of infections. Untreated HIV reduces the number of CD4 cells in the body,

How to cite: Slabbert 'Solid organs transplanted from HIV-positive dead donors to HIV-negative recipients: should it be allowed?' 2017 De Jure 363-377

http://dx.doi.org/10.17159/2225-7160/2017/v50n2a9 
syndrome. In the years to follow there have been significant developments in HIV research and treatment, allowing HIV-positive individuals to live decades longer than originally anticipated. ${ }^{4}$ In 2013 the United States Senate passed the HIV Organ Policy Equality Act, or HOPE Act, ${ }^{5}$ which changed it all. From then on it was permitted to transplant solid organs from HIV-positive donors into HIV-positive recipients. ${ }^{6}$

South Africa does not have a similar legislative prohibition on the usage of HIV-positive solid organs. ${ }^{7}$ In other words, there is no piece of legislation or regulation stipulating specifically that HIV-positive people cannot donate their organs. It is common practice though, in hospitals where transplants are performed, not to use the organs of an HIVpositive donor. 8

There is a huge demand for transplantable solid organs in South Africa, and the supply is not nearly enough to fulfil the demand. ${ }^{9}$ HIV-positive people were until recently not even admitted on a transplant waiting list due to the possible poor outcome of a transplant. However, highly active antiretroviral therapy has reduced morbidity and mortality of HIVinfected people. ${ }^{10}$ Research has also shown that an HIV-positive donated solid organ can be transplanted into an HIV-positive recipient without any detrimental effects. ${ }^{1}$ Studies have also shown that HIV-positive patients who required organ transplants fared well after receiving an

making the person more likely to get other infections. No effective cure currently exists, but with proper medical care, HIV can be controlled. The medicine used to treat HIV is antiretroviral therapy. If taken the right way and daily an infected person can dramatically prolong his or her life. Today someone with HIV which is treated correctly can live nearly as long as someone who does not have HIV. See Centers for Disease Control and Prevention 'About HIV/AIDS' 2016 available from http://www.cdc.gov/hiv/ basics/whatishiv.html (accessed 2016-10-07).

4 HIV 2 HIV 'The history of the National Organ Transplant Act (NOTA)' 2012 available from http://hiv2hiv.org/history.php (accessed 2016-09-29).

5 Public Law 113-51, November 21, 2013.

6 Christensen 'In a first, HIV-positive donor's kidney, liver given to HIVpositive patients' 2016 available from http://edition.cnn.com/2016/03/30/ health/hiv-first-successful-transplant/index.html (accessed 2016-09-14).

7 Solid organs for this article include the kidneys, heart, lungs, liver and pancreas.

8 See the SA Renal Society, SA HIV Clinicians Society, the Department of Health and the SA Transplant Society's 'Guidelines for renal replacement therapy in HIV-infected individuals in South Africa' 2007; Barday et al 'Guidelines for renal replacement therapy in HIV-infected individuals in South Africa' 2008 The Southern African Journal of HIV Medicine at 34-42.

9 At Groote Schuur Hospital the number of deceased donor referrals has halved in the past 10 years. See Muller et al 'Renal transplantation between HIV-positive donors and recipients justified' 2012 SAMJ; Organ Donor Foundation 'Statistics' 2016 available from https://www.odf.org.za (accessed 2016-09-27).

10 Muller et al 2012 SAMJ at 497

11 Idem at 497-498; Muller et al 'HIV-positive-to-HIV-positive kidney transplantation - results at 3 to 5 years' 2015 The New England Journal of Medicine (NEJM) at 613-620. 
organ from another HIV-positive donor. ${ }^{12}$ Until 2004, HIV-infected patients were deemed unsuitable for transplantation owing to the dangers of using immunosuppressive anti-rejection drugs in the absence of highly active antiretroviral therapy. This fear has been abated as good outcomes have been confirmed after transplantation in HIV-infected persons receiving highly active antiretroviral therapy combined with anti-rejection drugs. ${ }^{13}$

The question now is whether it should be permissible to transplant a solid organ donated by a HIV-positive donor to a HIV-negative recipient. The question on its own raises legal and ethical concerns but, before the question can be answered, it is important to address the reasons why HIV-positive organs should ever be used for HIV-negative patients. Is it because the donor pool of organs is so limited? Should other ways of persuading more people to become organ donors not be fully exhausted before even thinking of using HIV-positive organs for HIV-negative recipients?

The concerns of using HIV-positive organs for HIV-negative recipients are addressed under three categories namely: consenting adults, ${ }^{14}$ children and lastly whether such transplants should not be seen as experimental in nature and therefore research. The last category has its own special legal requirements. Other ways not yet legally permitted in South Africa to get more donated organs are briefly discussed and, in conclusion, it is recommended that HIV-positive solid organs should not be transplanted into HIV-negative recipients, as other ways of procuring organs for transplantation could increase the donor pool more effectively.

\section{Transplantations: HIV-Positive to HIV-Negative}

\section{Consenting Adults}

The principle that an adult has consented to a risk associated with a medical procedure is embodied in the Latin maxim volente non fit iniuria - meaning a willing person is not wronged, or he who consents cannot be injured. The maxim has its origins in Roman and Roman-Dutch law. ${ }^{15}$ Currently it could be seen as entrenched in the Constitution of the Republic of South Africa, 1996 (the Constitution) section 12(2) which determines that everyone has the right to bodily and psychological integrity, which includes the right to security in and control over their body. In other words any person has a constitutional protected right to decide what should happen to his or her body, yet, the law is clear that

\section{Ibid.}

13 Supra n 10 at 497.

14 Adults in this article refer to adults capable of making decisions on their own in other words having legal capacity to act.

15 Neethling \& Potgieter Law of delict (2010) at 104. 
when decisions concerning the body are taken, the decision must be made with the informed consent of the person making the decision.

The constitutional right of deciding what should happen to your body is underlined in the National Health Act 61 of 2003 (NHA) in sections 6 'User to have full knowledge', 7 - 'Consent of user' and 8 - 'Participation in decisions'. The doctrine of informed consent was also confirmed in the case of In Castell $v$ De Greef. ${ }^{16}$ The court referring, with approval at page $425 \mathrm{H}-\mathrm{I}$ of the judgment to the doctoral thesis of Prof Van Oosten on The doctrine of Informed Consent, to the following requirements for consent to be valid:

(a) The consenting party must have had knowledge and been aware of the nature and extent of the harm or risk;

(b) The consenting party must have appreciated and understood the nature and extent of the harm and/or risk;

(c) The consenting party must have consented to the harm or assumed risk;

(d) The consent must be comprehensive, that is extend to the entire transaction, inclusive of its consequences. ${ }^{17}$

Carstens and Pearmain ${ }^{18}$ also point out with reference to the purpose and function of the doctrine of informed consent, that pivotal to its application, is an understanding of the broader purpose and function of the doctrine which are two-fold: First, to ensure the patient's right to selfdetermination and freedom of choice; and secondly, to encourage rational decision-making by enabling the patient to weigh and balance the benefits and disadvantages of the proposed intervention, in order to come to an enlightened choice either to undergo or refuse treatment. Thus, according to Carstens and Pearmain, the physician is obliged to:

- Give the patient a general idea in broad terms, and

- in a layperson's language; of the nature, scope, consequences, risks, dangers, complications, benefits, and disadvantages of the procedure as well as the alternatives to the proposed intervention, and the patient's right to refuse treatment. ${ }^{19}$

In the context of using an HIV-positive solid organ for transplantation into an HIV-negative recipient, it means that the receiver of the infected organ should give informed consent as described above, before such an endeavour could be undertaken. As there is currently no legislative ban on transplanting an HIV-positive solid organ into an HIV-negative recipient, it could legally be done after the giving of informed consent. Ethically the question could be asked whether it should be allowed, as such practice would run counter to extensive public health efforts to minimise HIV transmission. It could also put intimate partners of organ

16 Castell $v$ De Greef 19944 SA 408 (C).

17 Supra $\mathrm{n} 15$ at $106-107$.

18 Carstens \& Pearmain Foundational Principles of South African Medical Law (2007).

19 Idem at 884. 
recipients at risk. ${ }^{20}$ It should thus only be done in rare cases where the risks of HIV infection are clearly outweighed by the risks of continuing to wait for a transplant. The need to transplant an HIV-positive solid organ into an HIV-negative recipient may exist when a patient's medical urgency for a transplant is so severe that the risks of waiting include imminent death. ${ }^{21}$ It should also only be done with the recipient's informed consent in the broadest terms possible. Meaning the recipient should understand that he or she will probably be HIV-positive after the transplant. Such a recipient should also appreciate the fact that he or she should be on medication for the rest of his or her life and that his or her intimate relatives might also be affected. In other words, the consent should comply with the requirements as quoted in the Castell case.

As indicated at the beginning of this section informed consent is an explicit requirement for any medical intervention. It could be argued that a desperate patient whose only other option is death, cannot really give informed consent to receive an infected solid organ. Apart from being desperate to stay alive, albeit by accepting an infected heart or lungs, the risks associated with the procedure can also not be explained in detail to the patient by the physician, as there is still uncertainty as to what the effect of an HIV-positive organ might be on an HIV-negative recipient.

No transplant is ever guaranteed to be a success, and recipients are always warned about the possibility of receiving an infected organ. Because time is of the essence in solid organ transplants, it might happen that an HIV-negative person receives an HIV-positive solid organ accidentally. In this instance, the informed consent was given by the recipient for a transplant while knowing clearly the risks associated with the operation. An unfortunate scenario like this might happen because of the window period for HIV to manifest. During the window period, a person can be infected with HIV and be very infectious but still test HIVnegative. ${ }^{22} 23$ Antibody testing at four weeks can give a good indication of HIV-status in an individual; this is impossible to do in a transplant context. When a patient is certified as brain dead, the question of organ donation might be raised. The blood flow of the deceased is then artificially maintained in order for the organs not to start deteriorating. Tests will also be done to see whether the deceased could be a donor, should the relatives consent to a donation. These tests are not always reliable because of the window period as discussed above.

20 Mgbako et al 'Allowing HIV-positive organ donation: ethical, legal and operational considerations' 2013 American Journal of Transplantation (AM J Transplant) 3.

21 Ibid.

22 I-base 'What is the window period for an HIV test?' 2016 available from https://i-base.info/guides/testing/what-is-the-window-period (accessed 2016-09-26).

23 Wispelwey et al 'The transplantation of solid organs from HIV-positive donors to HIV-negative recipients: ethical implication' 2015 Journal of Medical Ethics (J Med Ethics) 367 where cases are discussed in which recipients received infected organs which tested negatively. 
Transplantations are unique therapeutic interventions with risks of rejection or receiving an infected organ. The supply of donated organs is not nearly enough for people requiring a transplant, especially the patients ranked lower on a transplant list, namely older adults. By using HIV-positive organs, many borderline adults who might never receive a transplant could be helped to live longer, instead of dying because there was no organ available. Seen in this context and the constitutional right to self-determination, as well as informed consent, it seems as if every adult patient should be allowed to decide whether to accept an infected solid organ for transplantation or not. However, even though it seems legally valid to consent to such a transplant, it is not yet practice in South African hospitals to use HIV-positive donated organs for transplantation into HIV-negative recipients. If it was to be done it should, therefore, be seen as experimental and research-based which requires strict legislative compliance as will be indicated later in the article.

\section{Children}

According to the Constitution, a child is a person under the age of 18 years and a child's best interests are of paramount importance in every matter concerning the child. ${ }^{24}$ The Constitution must be read with the Children's Act 38 of 2005. According to section 129 of the Children's Act, the parents (guardian) must give consent for medical treatment of a child between 0 and 12 years. After the age of 12 and if the child is sufficiently mature enough and has the mental capacity to understand the benefits and risks of the treatment, he or she must assent to the procedure with the parents or guardian.

In other words, the parents/guardian could decide for a child below the age of 12 to receive an HIV-positive solid organ for transplantation into the HIV-negative child. If the child is above the age of 12 , he or she should decide with the parents/guardian whether to accept such an infected organ, if he or she is mature enough to understand the risks. This could be a very difficult decision to make, either on behalf of the child or with the child. As there is no law prohibiting the transplantation from an HIVpositive donor to an HIV-negative recipient, it could happen that parents or guardians could be faced with such a choice between the death of their child or accepting an infected organ. Children are usually prioritised on organ waiting lists and therefore to transplant an HIV-positive organ into an HIV-negative child should happen only in very exceptional cases. As in the case of adults, set out above, because the transplantation of HIVpositive solid organs into HIV-negative children is not happening yet in South African hospitals, it should thus at this moment rather be viewed as research.

24 S 28 of The Constitution of the Republic of South Africa, 1996. 


\section{Research}

\section{Adults}

The Constitution states in section 12(2) that everyone has the right to bodily and psychological integrity, which includes the right not to be subjected to medical or scientific experiments ${ }^{25}$ without his or her informed consent. Informed consent has been discussed above and applies therefore in any research scenario as well. The Constitution should be read with the NHA which requires in section 11 - 'health services for experimental or research purposes' that, before treatment, the patient must be informed of the experimental or innovative status of the intended treatment (own emphasis). In other words, apart from just informing the patient about the risks and benefits of the procedure the physician responsible for the research project must also inform the patient of the innovative status of the treatment, in order for the patient to give informed consent. ${ }^{26}$ Carstens and Pearmain ${ }^{27}$ submit that in the context of medical research there should be 'full disclosure', meaning that the patient should be informed that the proposed medical intervention involves research. In addition, he or she must be furnished with comprehensive and detailed information about amongst others:

- the precise nature, scope, purpose and duration of the proposed research project;

- is it randomised, a pilot study and/or controlled;

- the consequences of the proposed intervention;

- the anticipated benefits and advantages for the patient and society;

- foreseeable dangers and complications and that participation is voluntary.

They also underline the fact that in a research context the research subject should be given sufficient time to contemplate and decide on participation. $^{28}$

The NHA also gives statutory authority for governance of 'health research' and the necessary research ethics regulatory infrastructure. Section 71 of the NHA specifically addresses research or experimentation with human subjects. Section 73 determines that every organisation/ institution, health agency and health establishment at which health and

25 The term 'experiments' originates from Article 7 of the International Covenant on Civil and Political Rights - UN 1996 and echoes the Nuremberg Code; in the constitutional context, it is intended to mean 'research'.

26 Department of Health Republic of South Africa 'Ethics in Health Research: Principles, Processes and Structures - 2015' (hereafter Guidelines 2015) S 3.1.9; Venter $v$ Roche Products (Pty) Ltd (A11/2014) (2014) ZAWCHC 157 where informed consent in a research context is discussed. It concerns the payment of trial-related injuries bur also elaborates on informed consent.

27 Supra $\mathrm{n} 18$ at 894-895.

28 Supra n 18 at 895; Guidelines 2015 s 24 and s 25 'No person should be required to make an immediate decision'. 
health-related research involving human participants is conducted, must establish or have access to a registered Human Research Ethics Committee (REC). ${ }^{29}$ REC's that review research involving human participants must register with the National Health Research Ethics Council (NHREC). ${ }^{30}$ Mandated by section 72 of the NHA, the NHREC compiled guidelines 'Ethics in Health Research: Principles and Structures - 2015. ${ }^{39}$ The 2015 Guidelines refers to the ethical principles of beneficence and non-maleficence meaning to maximise benefit and minimise harm as follows: 'Research that involves human participants should seek to improve the human condition. If the research cannot do this, then it is unlikely to be ethical'. 32 Concerning distributive justice (equality), it provides: 'there should be a fair balance of risks and benefits amongst all role-players involved in research, including participants, participating communities and the broader South African society., 33

In light of all of the above, to do research by transplanting an HIVpositive solid organ into an HIV-negative recipient, strict requirements will have to be met. There must be full disclosure of the envisaged research before informed consent could be given by the recipient as well as the approval of the research by a REC. This might be problematic as such transplants are not really improving the human condition, albeit that he or she will not die; he or she will have a life-threatening condition that would need constant medication. The REC's might have a problem with this double effect, and they might not approve it due to the fact that it will not necessarily maximise benefit and minimise harm. Even though it could be argued that informed adults, knowing that they will be part of an experiment, could give consent to receive an HIV-positive solid organ, it seems difficult to accept the benefit of living outweighing the harm done to the recipient.

\section{Children}

The NHA in section 71(2) states:

29 Chapter 4 of the Guidelines 2015.

$30 \mathrm{~S} 72$ of the NHA.

31 S 1.1.7 of the Guidelines 2015 'The core ethical principles outlines in these guidelines apply to all forms of research that involves living human participants and the use of animals, placing their safety, welfare and interests of both humans and animals as paramount'. S 1.8.3 These Guidelines should be read in conjunction with other guidelines such as the Department of Health (DoH) Guideline for Good Practice in the Conduct of Clinical Trials with Human Participants in South Africa (2006); the Human Sciences Research Council (HSRC) Ethics Guideline; and international guidelines such as the Declaration of Helsinki (2013); the Council for International Organizations of Medical Sciences (CIOMS) International Ethical Guidelines for Biomedical Research involving Human Subjects (2002); the ICH Harmonised Tripartite Guideline: Guideline for Good Clinical Practice E6 (R1) 1996; the ICH Harmonised Tripartite Guideline: Clinical Investigation of Medical Products in the Pediatric Population E11 200.

32 S 2.1 of The Guidelines 2015

$33 \mathrm{~S} 2.1$ of The Guidelines 2015. 
Where research or experimentation is to be conducted on a minor for a therapeutic purpose, the research or experimentation may only be conducted -

(a) if it is in the best interests of the minor;

(b) in such manner and on such conditions as may be prescribed;

(c) with the consent of the parent or guardian of the child; and

(d) if the minor is capable of understanding, with the consent of the minor.

The Guidelines of 2015 determines that '.. anyone under the age of 18 years may not choose independently whether to participate in research; a parent or guardian must give permission for the minor to choose'. ${ }^{34}$ It goes further to state: '... minors should participate in research only where their participation is indispensable to the research, meaning the research cannot deliver the desired outcomes if adult participants were to be used instead.' 35 The minimum conditions for research involving minors are amongst others that it should pose acceptable risks of harm; not be contrary to the best interests of the child and written permission must be given by a parent/guardian despite the Children's Act 38 of 2005 sections 129 and the Choice on Termination of Pregnancy Act 92 of 1996 s 5(2). If possible, the child must assent in writing as well. ${ }^{36}$

Taking the above into consideration, it could never be in the best interest of the child to infect him or her with HIV, and it thus seems that children should never be used in an experiment to find out the effect of transplanting an HIV-positive organ into an HIV-negative recipient.

\section{Discussion}

There is a small pool of donated solid organs. To discard HIV-positive donated organs could have a huge impact on the organ pool. 37 'The evergrowing disparity between the number of donated organs and the number of wait-listed patients has created an ethical imperative for transplant clinicians to seek novel methods of expanding transplant access. ${ }^{38}$ But, given the risks associated with transplanting an HIVpositive organ into an HIV-negative recipient, if novel ways are used, it should first take place using only organs from donors with well-controlled HIV and no history of opportunistic infections. Ideally, these infected donors should have a stable, well-characterised HIV infection which existed for a substantial period prior to brain injury. This will help

34 S 3.2.2. of The Guidelines 2015.

35 S 3.2.2.1 of The Guidelines 2015.

36 S 3.2.2.1-3.2.2.5 of The Guidelines 2015.

37 There was a 10-20\% HIV seroprevalence in potential donors referred to transplant co-ordinators in Cape Town and Johannesburg. See Muller et al 2012 SAMJ 498.

38 Mgbako et al 2013 Am J Transplant 3; S 2.3.1 of The Guidelines 2015 states: 'Research should be relevant and responsive to the needs of the people of South Africa' - If more people could live even with a HIV-positive organ it could be argued that this requirement will be fulfilled. 
transplant teams to obtain important information on the donor virus, such as historical genotype patterns and current viral load. These restricted criteria could then be relaxed over time if outcomes among recipients are favourable. 39

Highly active antiretroviral therapy has also reduced the morbidity and mortality of HIV-infected people. In other words, it is not a death sentence anymore to be HIV-positive. It could thus be argued that you are in fact better off with an infected organ than without an organ facing death. The concern about potential interactions between antiretroviral and immunosuppressive agents is also unnecessary as experienced centres routinely monitor blood levels of these agents and adjust doses accordingly. ${ }^{40}$ Doctors at a hospital in France did a study of the drug to drug interaction between antiretroviral medication and immunosuppressive drugs. They came to the conclusion that careful monitoring for interactions between immunosuppressant drugs and antiHIV medication is required in order to ensure that effective therapy for both HIV and rejection is sustained. A multi-disciplinary team should therefore evaluate and care for the patient. These specialists should include people with expertise in HIV, transplantation and pharmacology. ${ }^{41}$ These medication-related issues should also be explained to the prospective infected organ receiver as it should form part of the risks associated with the transplant. The recipient should understand the problems concerning the drugs he or she will have to take post-transplantation in order to give full informed consent.

It can further be argued that to deny patients the right to take on the risks of HIV-infection when a transplant is the only recourse available to stay alive would be a unique limit on autonomy. ${ }^{42}$ It should be left to the patient opting for a transplant knowing the solid organ is infected with HIV to determine whether the risks associated with HIV-infection are reasonable in relation of the benefit - to have life. ${ }^{43}$

Currently by way of practice and not because of a legal ban, HIVpositive solid organs are singled out as a severe medical criterion listed as an absolute ban to donation for transplantation. This might even be seen as discrimination against HIV-positive people, as it is an exclusion of the HIV-positive population from the psychological benefits that accrues from knowing one might become a donor after death. This prohibition might also have an impact on the families of HIV-positive individuals given that donor families gain psychological relief that the

39 Supran 20 at 3.

40 Roland et al 'Clinical, ethical, and policy issues in the evaluation of the safety and effectiveness of solid organ transplantation in HIV-infected patients' 2003 Archives of Internal Medicine Journal (Arch Intern Med) 17731778.

41 Izzedine et al 'Antiretroviral and immunosuppressive drug-drug interactions: An update' 2004 Kidney International 532-541.

42 Supran 23 at 369.

43 S 3.1.6 of The Guidelines. 
donor's death helped others. ${ }^{44}$ But, despite all arguments for the use of HIV-positive solid organs, it should like in the United States of America, only be used for HIV-positive patients. HIV-negative patients should have the right to receive as far as possible, a HIV-negative solid organ, therefore other ways of increasing the donor pool that have not yet been explored in South Africa, should first be exhausted before the transplantation of a HIV-positive organ into a HIV-negative recipient is undertaken.

\section{Possible Other Solutions to the Organ Shortage}

When one conscientiously considers the benefits and risks associated with transplanting a HIV-positive organ to a HIV-negative recipient, one is faced with the question of whether all other possible solutions have been exhausted that it is necessary to take such desperate measures. The answer to this question is simple; there are other solutions that have not yet been tried and tested in South Africa which could be a possible solution to the acute organ shortage. It must be noted that the foreign systems referred to are not flawless. Yet, the systems are a step in a positive direction to attempt to change the current dire situation. The Constitution encourages us to consult international and foreign law when developing legislation. ${ }^{45}$ Hereafter, a short discussion will follow on the approaches that have been successfully followed by other countries:

\section{Point System: Israel}

The acute organ shortage is not a dilemma which is only faced by South Africa but in fact a predicament that a number of countries find themselves in. These other countries have taken the necessary steps to implement new procedures when it comes to organ transplants. In 2010 , Israel implemented a new law governing organ donation and allocation namely the Organ Transplant Act (2008). The aim of the Act is mainly to increase the number of organ donations by introducing a priority point system. ${ }^{46}$ The system motivates individuals to sign donor cards or to consent to the donation of the organs of a first-degree relative. In a nutshell, this system creates a tiered system of priority which includes the following: maximum priority, regular priority and second priority. ${ }^{47}$ To obtain maximum priority a candidate has two options; he can either give consent for organ donation from a deceased first degree relative or he donated a kidney, a liver lobe, or a lung lobe in the course of his lifetime to a non-specified recipient. ${ }^{48}$ Regular priority is granted to candidates who hold a donor card and have consented to donate their

44 Supra $\mathrm{n} 20$ at 3.

45 S 39(1)(b) and (c) of the Constitution.

46 Slabbert \& Venter 'Organ procurement in Israel: Lessons for South Africa' (2015) SAJBL 44.

47 Quigley Wright \& Ravitsky 'Organ donation and priority points in Israel: An ethical analysis’ 2012 Transplantation 971.

48 Ibid. 
organs after death. ${ }^{49}$ Those candidates who do not hold a donor card themselves, but has a first-degree relative who holds a donor card are granted second priority. ${ }^{50}$ If a similar priority system is introduced in South Africa it could serve as a motivation and recognition of potentially registered organ donors. The system could also potentially bring an element of fairness to the organ donation process.

The downside of the Israel system is that medical care should be allocated on the basis of medical need and not on extraneous factors. To prefer those willing to be organ donors could create the perception that organ donation status is related to a person's moral worth and this could begin a trend for other types of moral worth variables in the organ allocation equation. 51

\section{Opting In and Routine Referrals: Spain}

When a country is experiencing an acute shortage of organs available for transplantation one of the first measures they usually take is to amend their organ procurement system. Internationally, countries either follow an 'opt-in' or 'opt-out' system. ${ }^{52}$ Opt-in is an altruistic form of organ donation which focuses on consent from the donor. The donor either consents to a living donation during his lifetime or he consents to donate his organs at his death, ${ }^{53}$ whereas, opt-out focuses mainly on deceased donors. According to the opt-out system, every citizen of that specific country is automatically considered an organ donor unless the individual registers his objection to being an organ donor. ${ }^{54}$ Spain has benefited immensely from their opt-out system and currently has the highest organ donation rate in the world. ${ }^{55}$ Yet, it seems that the Spanish model's success could also be credited to their transplant co-ordination network and routine referral system. ${ }^{56}$ The routine referral system is based on a basic principle which requires the treating physician to routinely and timeously refer the possible brain or cardiac death of a potential donor to the transplant co-ordinator. ${ }^{57}$ In South Africa, routine referral is not commonly practised due to a number of reasons such as time

49 Ibid.

50 Ibid.

51 Guttman 'Laypeople's ethical concerns about new Israeli organ transplantation prioritization policy aimed to encourage organ donor registration among the public' 2011 Journal of Health Politics, Policy and Law 691-716

52 Slabbert 'Combat organ trafficking - reward the donor or regulate sales' 2008 Koers 77.

53 Shepherd O'Carroll \& 'Ferguson 'An international comparison of deceased and living organ donation' 2014 BMC Medicine (BMC Med) 131.

54 Schicktanz Wiesermann \& Wohlke Teaching ethics in organ transplantation and tissue donation (2010) 4.

55 McIntosh 'Organ Donation: is an opt-in or opt-out system better?' 2016 available from www.medicalnewstoday (accessed 2016-12-08).

56 Ibid.

57 Dominguez-Gil Murphy \& Procaccio 'Ten changes that could improve organ donation in the intensive care unit' 2016 Intensive Care Medicine (Intensive Care Med) 265. 
constraints, lack of education and awareness regarding organ transplants as well as an acute staff shortage. It could be a considered as a first, minute step in the right direction if a routine referral policy is implemented compelling physicians to refer every death to be evaluated for the possibility of organ harvesting. When considering all of the above it can be inferred, the routine referral system and transplant coordination networks need to work hand in hand to achieve optimal success. ${ }^{58}$

The Spanish transplant co-ordination network operates at three levels: national, regional and hospital. For purposes of this paper there will be a brief focus only on the hospital level. The Spanish transplant coordinators have a unique profile where they facilitate early identification and referral of potentials donors. ${ }^{59}$ The hospital level of co-ordination is represented by a network of officially authorised procurement hospitals, this network grew from less than 20 hospitals in 1989, to 118 in 1992 , and has continued to increase to 170 hospitals in $2009 .{ }^{60}$ Whereas, in South Africa there is an approximate number of 20 transplant coordinators which serve both the public and the private sector. Since, South Africa already has a basic transplant co-ordination network and routine referral process in place it would be more sensible to try and expand and improve the network and process before relying on other drastic solutions as discussed above.

\section{Rewarding the Donor: Singapore}

Singapore, similar to other countries has made several changes to their transplant legislation. In 2008, The Human Organ Transplant Act $(H O T A)^{61}$ was amended and some of the major changes included adopting an opt-out organ procurement system and making provision for the reimbursement of living donors. ${ }^{62}$ According to section 14(3)(c)(ii) of HOTA a donor can be reimbursed for the following costs or expenses; the costs of travel, accommodation, domestic help or child care or loss of earning as far as reasonably or directly attributable to the donor supplying his kidney. Furthermore, section 14(3)(c)(iii) stipulates that the donor will be reimbursed for any short-term or long-term medical care or insurance protection that may be reasonably necessary as a consequence of the donation. The reimbursement approach followed by Singapore could serve as a perfect example for South Africa due to the

58 See Slabbert and Venter 'Routine referrals: A possible solution for transplantation shortages' 2017 The South African Journal of Bioethics and Law 15.

59 In South Africa this process is usually done by the junior doctor on duty in the intensive care or trauma unit until a transplant co-ordinator becomes available.

60 Matesanz et al 'Spanish experience as a leading country: what kind of measures were taken?' 2011 Transplant International 334.

61 Human Organ Transplant Act 1987 (hereinafter 'HOTA').

62 Slabbert \& Venter 'Rewarding a living kidney donor: a comparison between South Africa, Singapore and Iran' 2013 Obiter 187. 
cultural and religious similarities that the countries share. The National Health Act 61 of 2003, already makes preliminary provision for the reimbursement of a living donor in section 60(4)(a), which stipulates that the donor may be reimbursed for the reasonable costs incurred by him to provide a donation. ${ }^{63}$ As yet, it has not been decided what will be regarded as reasonable costs and who will take responsibility for these reasonable costs within the South African framework. The legislature could rely on section 14(3)(c)(ii) and (iii) of HOTA to assist in the interpretation and development of section 60(4)(a) of the NHA to avoid further uncertainties and to secure more living donors for the future to improve the current organ shortage.

\section{Paying the Donor: Iran}

Iran has by far achieved the greatest success with its radical Iranian model of paid kidney donations which was established in $1988 .^{64}$ To summarise the model entails a government-funded, regulated and compensated living, unrelated donor renal transplantation programme. In the early 1980's the model started out as an unregulated international market but eventually the Iranian Ministry of Health became involved with the practice, due to the communities' fear of potential exploitation, manipulation and unfair treatment involved within the process. ${ }^{65}$ Before, the implementation of the model, Iran was experiencing a drastic, escalating number of patients with end-stage renal failure. ${ }^{66}$ To exacerbate the situation Iran did not have a deceased-donor organ programme or any future plans for such a programme. ${ }^{67}$ The Iranian Patients' Kidney Foundation ${ }^{68}$ was and continues to be the main key player in the process; they register the statistics and information of both candidates for kidney transplants and willing donors into a database to find a match for each party. ${ }^{69}$ Once, the proper consent is obtained the IPKF introduces the newly matched pair to each other, and the pair comes to an agreement on an acceptable price to be paid from the kidney recipient to the potential donor of the kidney. It is indeed an exceptionally sophisticated system which does not leave any gap for an organ broker (agency) or transplant tourism. ${ }^{70}$ The Iranian model provides a plethora of benefits such as an eradication of organ trafficking in Iran, an increased amount of living donations and the promotion of autonomy and control over one's body and choices. A disadvantage of the model is the reliance on the poorer population for the supply of

\footnotetext{
63 Ibid.

64 Bagheri 'Compensated kidney donation: an ethical review of the Iranian model' 2006 Kennedy Institute of Ethics Journal (Kennedy Inst Ethics J) 270.

65 Potter 'Does the Iranian Model of kidney donation compensation work as an ethical global model' 2015 Online Journal of Health Ethics (OJHE).

66 Supra $\mathrm{n} 62$ at 187.

67 Ibid.

68 Hereinafter referred to as IPKF.

69 Supra $n 65$.

70 Rupert 'Paying kidney donors: time to follow Iran?' 2008 McGill Journal of Medicine 68.
} 
organs. ${ }^{71}$ When compared with the rewarding-the-donor-approach followed by Singapore, it could be argued that rewarding the donor would be a more sensible starting point for South Africa. The Iranian Model could perhaps be perceived by the South African community as a tad ambitious and ahead of its time. Yet, we feel it should even be considered before condoning the transplantation of solid organs from HIV-positive donors to HIV-negative recipients

\section{Conclusion}

To transplant of solid organs has proven successful in many instances; the only limitation is the lack of donor organs. Many organs are rejected because of the desire to ensure that donated organs are disease free. 'The acute need for effective screening has been heightened by modern immunosuppression, the double-edged sword that has made transplantation so successful but also puts the recipient at an ever-greater risk of infectious disease infection or reactivation., ${ }^{72}$ The consequences of failing to get an organ for transplantation in time are grave and well documented, yet, the burden of HIV on individuals on chronic immunosuppressive medication has been shown to be acceptable. ${ }^{73}$

Legislation does not prohibit the transplantation of an HIV-positive organ into an HIV-negative recipient; this should stay as is. At the end, it is not a legal question but rather an ethical one. In our Constitutional dispensation, with the emphasis on personal autonomy, every adult patient should decide for himself or herself whether to live rather than to die because of the unavailability of an HIV-negative donor organ albeit on lifelong antiretroviral drugs treatment. A transition to such a practice should be thought through and if none of the other options seem to be better, be stepwise, starting with a research group of consenting patients. As Wispelwey et al. concludes: 'Given the data on organ availability and the post-transplantation risks that are currently deemed acceptable, there appears to be little reason for the medical community and broader society to reject this opportunity. ${ }^{, 74}$

71 Supra $\mathrm{n} 65$.

72 Supra $\mathrm{n} 23$ at 367.

73 Supra $\mathrm{n} 23$ at 369.

74 Supra $\mathrm{n} 23$ at 370. 